\title{
Evolution of chemical composition, somatic cell count and renneting properties of the milk of Massese ewes
}

\author{
C. Pugliese, A. Acciaioli, S. Rapaccini, G. Parisi, O. Franci* \\ Dipartimento di Scienze Zootecniche dell'Università di Firenze, via delle Cascine 5, 50144 Florence, Italy
}

Accepted 8 June 1999

\begin{abstract}
The experiment was carried out on 52 lactations of 37 multiparous Massese ewes. Because of the mating practice of the breed, three types of lactation were detected: Type 1, a short lactation initiated in autumn; Type 2, a short lactation initiated in spring, following the Type 1 lactation; Type 3, a long lactation initiated in autumn. Milk yield was recorded weekly, starting not before the eighth day from lambing. On a total 984 milk samples, contents of fat, protein, casein and lactose, SCC, $\mathrm{pH}$ and clotting parameters (R, K20 and A30) were determined. Data were analysed by a mixed model including lactation order, lactation type, DIM, and individual lactation as random effects. Protein and casein content increased from the second to fifth lactation; the highest fat content was detected in the sixth lactation and over; milk of fourth lactation had higher SCC and worse renneting properties than that of second lactation. The pattern of evolution of parameters within the three types of lactation showed that the increase of nutrients with DIM was particularly noticeable for fat content in the Type 2 lactation (spring/short) which exhibited, at an average of 94 DIM, 1.5 percentage units above the other two types. Evolution of lactodynamographic parameters indicates that generally there was a substantial improvement in cheese-making suitability during the first $2-3$ months postpartum, and a worsening thereafter. The Type 2 lactation yielded milk with better renneting properties, particularly with respect to milk obtained during the same season from ewes that had an autumn delivery. This suggested that the newly started milk from the spring lactation could have a corrective effect on the total amount of bulk milk produced, a possible advantage for the Massese breed, which is characterised by a particularly pronounced deseasonalisation of lambings. (C) 2000 Elsevier Science B.V. All rights reserved.
\end{abstract}

Keywords: Massese sheep; Milk constituents; Renneting properties; Lactation stage; Lactation type

\section{Introduction}

The chemical composition of sheep's milk is very variable because of genetic and environmental factors. The breed itself is a factor in milk composition

*Corresponding author. Tel.: +39-55-328-8263; fax: +39-55321-216.

E-mail address: franci@zoot.agr.unifi.it (O. Franci)
(Barillet, 1985; Sakul and Boylan, 1992) but within breeds the most significant compositional variations are determined by the stage of lactation as shown by Casoli et al. (1989), Marìa and Gabiña (1993), Delacroix-Buchet et al. (1994), Gonzalo et al. (1994), Carta et al. (1995), Hassan (1995) and Cappio-Borlino et al. (1997). Sheep have, moreover, a particular reproductive rhythm relating to individual breeds and to external factors of climate and breeding environment, and 
the seasonality of lambing, which is common to several breeds, often prevents the effects of stage of lactation, season, and nutrition from being distinguished separately (Pellegrini et al., 1994). Sheep's milk, unlike cows' or goats' milk, is also used almost exclusively for the production of cheese so that its quality is based not only on its nutrient content but also on its renneting ability, a key factor in cheese yield. Informations on factors affecting the technological characteristics of sheep's milk are scarce and research on the evolution of lactodynamographic parameters during lactation has been limited (Ubertalle et al., 1991; Delacroix-Buchet et al., 1994).

The Massese breed is one of the most important Italian sheep breeds, producing about $200-300 \mathrm{~kg}$ of milk per lactation. The breed originated in the northwest of Tuscany from where it spread to the whole of central Italy. Its reproductive performance is characterised by the partial aseasonality of oestrus which can occur at any time during the year, though lambings are more frequent in autumn and spring. The mating season is therefore continuous and the breeder can increase the lambings frequency in the flock by leaving the rams among freshly lactating ewes. Lactation generally starts in late summer or autumn and lasts until May-June, but is frequently interrupted after a few months by another pregnancy, followed by a new, shorter lactation next spring. In practice this means that Massese ewes normally have three lambings every two years, alternating two short lactations one year with one long lactation the next year. In at least some parts of the year a late stage of lactation in some animals therefore coincides with an early lactation in others, and each of these lactations contributes its compositional characteristics to the bulk milk produced.

The present study was undertaken to examine the evolution of the chemical composition and technological properties of the individual ewe's milk in these three types of lactation, normally recognised for Massese, to provide information useful to the breeder choosing a reproductive frequency for his flock.

\section{Material and methods}

The experiment was carried out on 52 lactations of 37 multiparous Massese ewes from the same flock. The ewes were pastured year-round and housed nightly in barns where they were fed hay ad libitum plus $0.5 \mathrm{~kg}$ of concentrate per head per day. Milking was manual twice a day, generally at $6.00 \mathrm{a} . \mathrm{m}$. and 6.00 p.m. The test-day milk yield was recorded weekly during the entire lactation. The first record occurred between 8-15 days from lambing when the newborns were separated from their mothers. As described in a previous paper (Franci et al., 1999) the first 37 lambings occurred in autumn (SeptemberNovember), after which all the ewes were again continuously exposed to mating, according to the usual breeding system with Massese, that leaves the ram in the flock year-round. Fifteen ewes then conceived and lambed again in March-April, after a dryoff period of about one month. As a consequence it was possible to identify three types of lactation: Type 1, a short lactation that started in autumn (September, 14 lambings; October, 1 lambing) and lasted for an average of 136 days (s.d.=19.5); Type 2, a short lactation that started the following spring (March, 14 lambings; April, 1 lambing) and lasted 93.7 days (s.d.=9.3); and Type 3, a long, uninterrupted lactation which also started in autumn (September, 3 lambings; October, 5 lambings; November, 14 lambings) and which lasted for an average of 204.5 days (s.d.=51.6). Five orders of lactation were identified (from 2 to 6 ) and lactations over the sixth order were classed as 6 .

Once a week, equal quantities of the morning and afternoon milk were collected into a single test-day individual sample and analysed. On a total of 984 samples so collected, contents of fat and lactose were determined by the automated infrared method using a Milko Scan (AS/ N. Foss Electric, Hilleroed, Denmark); contents of protein and casein were determined by Kjeldahl method; casein was obtained by precipitation with acetic acid (ASPA, 1995) on about $66 \%$ of the samples; and the somatic cell count (SCC) was made with a Fossomatic cell counter 360 (AS/N. Foss Electric), calibrated according to the official method (ASPA, 1995) employed in field recording for Italian sheep breeds. A few hours after the second test-day milking, the $\mathrm{pH}$ and clotting parameters: $\mathrm{R}$ (renneting time), K20 (rate of firming) and A30 (curd firmness) were also determined using a formagraph apparatus according to official procedure (ASPA, 1995).

In order to normalise the SCC, values were transformed logarithmically $(\log (\mathrm{SCC}))$. Data were analysed by the statistical package PROC MIXED (SAS, 
1996) according to the following model:

$$
Y_{i j k l}=a+\mathrm{Or}_{i}+T_{j}+L_{k}+b_{j} * \mathrm{DIM}+E_{i j k l},
$$

where $Y_{i j k l}$ is the observation on $l$ th test day, $a$ the intercept, $\mathrm{Or}_{i}$ the fixed effect of the $i$ th lactation order $(i=1-5), T_{j}$ the fixed effect of the $j$ th lactation type $(j=1-3), L_{k}$ the random effect of the $k$ th lactation, and $b_{j}$ is the intraclass regression coefficient on days in milk (DIM). Regression was tested up to the third degree; $E_{i j k l}$ is the residual effect.

\section{Results and discussion}

Table 1 shows the statistics of the parameters studied. On the whole the daily milk yield was somewhat high and markedly variable, while the chemical parameters exhibited smaller variation. Of these chemical parameters lactose was the most constant, confirming its role as an osmotic regulator and a compensator for variations in all the other components (Bertoni, 1996). The average values for the fat and protein contents were consistent with those found in other dairy sheep breeds (Flamant and Casu, 1977; Barillet and Boichard, 1987; Sakul and Boylan, 1992; Gonzalo et al., 1994; Cappio-Borlino et al., 1997) and in the Massese breed (Casoli et al., 1989). Values for $\mathrm{pH}$ exhibited only moderate variation but all renneting parameters had a high CV at about $50 \%$. Since records were kept for a year, the variability observed, particularly high for milk yield and renneting properties can be attributed to weather and weather-dependent food availability in Mediterranean area, as well as to the individual and group factors (lactation order and stage) considered in this study.

\subsection{Effect of lactation order on milk traits}

The results relating to the effect of lactation order are shown in Table 2. No significant influence for milk yield emerged although values increased until the fourth lactation and decreased thereafter. Marìa and Gabiña (1993) studying the Latxa breed also found a maximum daily yield in the fourth lactation, while Casoli et al. (1989) working with Massese sheep found the maximum total milk yield at the third lactation.

Protein and casein concentrations were at the lowest level in milk from the second lactation, increased up to the fifth lactation, then decreased again at the sixth lactation and beyond. Fat content remained basically constant until the fifth lactation, after which it increased. This finding is only partly in agreement with Casoli et al. (1989) who found that the sixth lactation produced the highest concentrations of both

Table 1

Descriptive statistics for composition and renneting properties of Massese milk of 52 lactations

\begin{tabular}{|c|c|c|c|c|c|c|c|c|c|}
\hline \multirow[t]{2}{*}{ Trait } & \multicolumn{4}{|c|}{ No. of observations } & \multirow[t]{2}{*}{ Overall mean } & \multirow[t]{2}{*}{ SD } & \multirow[t]{2}{*}{$\mathrm{CV}(\%)$} & \multirow[t]{2}{*}{ Minimum } & \multirow[t]{2}{*}{ Maximum } \\
\hline & Total & Type $1^{\mathrm{a}}$ & Type 2 & Type 3 & & & & & \\
\hline Days in milk & 988 & 249 & 160 & 579 & 93.7 & 60.1 & 64.17 & 8 & 288 \\
\hline Milk yield $\left(\mathrm{g} \mathrm{d}^{-1}\right)$ & 988 & 249 & 160 & 579 & 1150 & 508 & 44.16 & 200 & 3100 \\
\hline Protein $(\%)$ & 982 & 247 & 159 & 576 & 5.75 & 0.88 & 15.36 & 3.71 & 9.29 \\
\hline Casein (\%) & 648 & 165 & 106 & 377 & 4.42 & 0.76 & 17.22 & 2.43 & 6.97 \\
\hline Fat $(\%)$ & 974 & 245 & 158 & 571 & 6.24 & 1.21 & 19.46 & 2.40 & 10.44 \\
\hline Lactose $(\%)$ & 974 & 245 & 158 & 571 & 4.92 & 0.38 & 7.76 & 3.41 & 6.18 \\
\hline $\mathrm{SCC}\left(\times 10^{3} \mathrm{ml}^{-1}\right)$ & 976 & 247 & 157 & 572 & 551.4 & 1142.9 & 207.27 & 17 & 8506 \\
\hline $\log (\mathrm{SCC})$ & 976 & 247 & 157 & 572 & 5.294 & 0.56 & 10.59 & 4.23 & 6.93 \\
\hline $\mathrm{pH}$ & 981 & 248 & 159 & 574 & 6.53 & 0.23 & 3.52 & 5.35 & 7.13 \\
\hline$R(s)^{b}$ & 928 & 235 & 155 & 538 & 1043 & 451 & 43.22 & 90 & 2670 \\
\hline $\mathrm{K} 20(\mathrm{~s})^{\mathrm{c}}$ & 915 & 230 & 153 & 532 & 190 & 115 & 60.82 & 60 & 1170 \\
\hline $\mathrm{A} 30(\mathrm{~mm})^{\mathrm{d}}$ & 982 & 247 & 159 & 576 & 46.7 & 23.1 & 49.48 & 0 & 73 \\
\hline
\end{tabular}

\footnotetext{
a Type $1=$ short lactation initiated in autumn; Type $2=$ short lactation initiated in spring; Type $3=$ long lactation initiated in autumn.

${ }^{\mathrm{b}}$ Renneting time in samples that clotted within $45 \mathrm{~min}$.

${ }^{\mathrm{c}}$ Rate of firming in samples that clotted within $45 \mathrm{~min}$.

${ }^{\mathrm{d}}$ Curd firmness.
} 
Table 2

Effect of the lactation order on test-day yield and qualitative and technological traits (least-squares means ( \pm s.e.) estimated at overall mean of DIM (93.7))

\begin{tabular}{|c|c|c|c|c|c|}
\hline & \multicolumn{5}{|c|}{ Lactation order } \\
\hline & $2(6)^{\mathrm{a}}$ & $3(9)$ & $4(10)$ & $5(9)$ & $\geq 6(18)$ \\
\hline Milk yield $\left(\mathrm{g} \mathrm{d}^{-1}\right)$ & $942 \pm 96$ & $963 \pm 79$ & $1058 \pm 79$ & $962 \pm 78$ & $910 \pm 53$ \\
\hline Protein $(\%)$ & $5.43 \mathrm{a} \pm 0.11$ & $5.80 \mathrm{bc} \pm 0.1$ & $5.80 \mathrm{bc} \pm 0.1$ & $6.02 \mathrm{c} \pm 0.1$ & $5.75 \mathrm{~b} \pm 0.07$ \\
\hline Casein $(\%)$ & $4.23 \mathrm{a} \pm 0.09$ & $4.52 b c \pm 0.08$ & $4.49 b c \pm 0.08$ & $4.66 c \pm 0.08$ & $4.46 \mathrm{~b} \pm 0.06$ \\
\hline Fat $(\%)$ & $6.45 a \pm 0.18$ & $6.49 a \pm 0.15$ & $6.53 b c \pm 0.15$ & $6.50 \mathrm{a} \pm 0.15$ & $6.89 \mathrm{~b} \pm 0.11$ \\
\hline Lactose $(\%)$ & $4.98 \pm 0.08$ & $5.00 \pm 0.07$ & $4.81 \pm 0.07$ & $4.95 \pm 0.07$ & $4.88 \pm 0.05$ \\
\hline $\log (\mathrm{SCC})$ & $4.96 \mathrm{a} \pm 0.20$ & $5.27 \pm 0.16$ & $5.65 \mathrm{~b} \pm 0.16$ & $5.41 \pm 0.16$ & $5.37 \pm 0.11$ \\
\hline $\mathrm{pH}$ & $6.46 \pm 0.04$ & $6.45 \pm 0.04$ & $6.5 \pm 0.04$ & $6.5 \pm 0.04$ & $6.51 \pm 0.03$ \\
\hline $\mathrm{R}(\mathrm{s})^{\mathrm{b}}$ & $783 a \pm 102$ & $1002 \pm 85$ & $1095 \mathrm{~b} \pm 87$ & $974 \pm 85$ & $1010 \mathrm{~b} \pm 60$ \\
\hline $\mathrm{K} 20(\mathrm{~s})^{\mathrm{c}}$ & $146 \pm 24$ & $177 \pm 21$ & $206 \pm 21$ & $146 \pm 20$ & $181 \pm 14$ \\
\hline $\mathrm{A} 30(\mathrm{~mm})^{\mathrm{d}}$ & $59 \mathrm{a} \pm 5.8$ & $49 \pm 4.8$ & $42 \mathrm{~b} \pm 4.8$ & $55 \pm 4.7$ & $48 \pm 3.3$ \\
\hline
\end{tabular}

$\mathrm{a}, \mathrm{b}, \ldots$. within the row means with different letters differ $(P<0.05)$.

${ }^{a}$ No. of lactations.

${ }^{\mathrm{b}}$ Renneting time.

${ }^{\mathrm{c}}$ Rate of firming.

${ }^{\mathrm{d}}$ Curd firmness.

fat and protein, and with Marìa and Gabiña (1993) in whose study lactation order affected only protein but not fat. Since at present Massese milk composition is not monitored in any way, selection by breeders in order to improve milk composition can be excluded and any such differences between lactations must be due solely to differences in metabolic performance between young and mature ewes. Our findings agreed with those of other researchers (Casoli et al., 1989; Peeters et al., 1992) in showing that the lactation order had no effect on lactose content, which was confirmed to be a component independent of the others.

SCC increased from the second to the fourth lactation (about $+14 \%$ on a logarithmic scale), after which it remained stable. The lactodynamographic parameters exhibited differences, statistically significant or at least in absolute value, mainly between the second and fourth lactation. Milk from the fourth lactation had a longer renneting time and a lower curd firmness. Since the $\mathrm{pH}$ level did not differ between lactations it is assumed that the renneting properties are related to SCC, which indicates the health of the udder, which itself decreases with age (Bergonier et al., 1996). The improvement of the cheese-making suitability of milk after the fourth lactation is in agreement with Casoli et al. (1989) and is probably due to farmer selection keeping alive only the best sheep after a certain parity. It is possible that since this selection was not based on the lactodynamographic parameters, which are not recorded, it was carried out on the basis of the health of the udder, which would be confirmed by the SCC patterns.

\subsection{Effect of type of lactation and stage of lactation on milk traits}

The effect of type of lactation, combined with the stage of lactation, is shown in Table 3 and displayed in Figs. 1-7. Table 3 shows estimates of the traits at the average DIM (93.7 days) and at an early stage of lactation (45 days). At 45 days, the DIM period was the average between the two dates $(30 / 60 \mathrm{~d})$ when monthly test records in practice initiate.

An earlier study (Franci et al., 1999) on the application of non-linear models for these milk yields showed that peak production was very early, at an average of 10 days postpartum. Since the present study, which is mainly concerned with milk quality variables, did not consider any control during the first week postpartum, as instead was done in the earlier paper (Franci et al., 1999), it was decided to use a linear model (a third degree regression) to study milk yield as well. The lactation curves for all three lactation types are therefore shown in their descending phase (Fig. 1). 
Table 3

Least-squares means $( \pm$ s.e. $)$ of the traits estimated at 45 DIM and at overall mean of DIM (93.7) for the three lactation types

\begin{tabular}{|c|c|c|c|c|c|c|}
\hline & \multicolumn{3}{|l|}{45 DIM } & \multicolumn{3}{|l|}{ 93.7 DIM } \\
\hline & Type $1^{\mathrm{a}}$ & Type 2 & Type 3 & Type 1 & Type 2 & Type 3 \\
\hline Milk yield $\left(\mathrm{g} \mathrm{d}^{-1}\right)$ & $1592 a \pm 65$ & $1527 \pm 71$ & $1424 b \pm 49$ & $942 \pm 64$ & $897 \pm 82$ & $1062 \pm 50$ \\
\hline Protein $(\%)$ & $4.94 \mathrm{a} \pm 0.08$ & $5.16 \pm 0.09$ & $5.17 \mathrm{~b} \pm 0.06$ & $5.60 \mathrm{a} \pm 0.08$ & $5.92 b \pm 0.12$ & $5.75 \pm 0.06$ \\
\hline Casein $(\%)$ & $3.76 \mathrm{a} \pm 0.07$ & $3.97 \pm 0.09$ & $3.97 \mathrm{~b} \pm 0.05$ & $4.38 \pm 0.08$ & $4.60 \pm 0.11$ & $4.43 \pm 0.05$ \\
\hline Fat $(\%)$ & $5.35 \pm 0.13$ & $5.64 \pm 0.14$ & $5.43 \pm 0.09$ & $6.12 \mathrm{a} \pm 0.13$ & $7.52 b \pm 0.19$ & $6.07 \mathrm{a} \pm 0.09$ \\
\hline Lactose $(\%)$ & $4.56 \mathrm{a} \pm 0.06$ & $5.50 \mathrm{c} \pm 0.06$ & $4.88 \mathrm{~b} \pm 0.04$ & $4.70 \mathrm{a} \pm 0.06$ & $5.14 \mathrm{c} \pm 0.08$ & $4.93 \mathrm{~b} \pm 0.04$ \\
\hline $\log (\mathrm{SCC})$ & $5.05 \pm 0.13$ & $5.18 \pm 0.14$ & $5.36 \pm 0.10$ & $5.30 \pm 0.13$ & $5.32 \pm 0.15$ & $5.38 \pm 0.10$ \\
\hline $\mathrm{pH}$ & $6.48 \pm 0.03$ & $6.51 \pm 0.03$ & $6.54 \pm 0.02$ & $6.41 \mathrm{~b} \pm 0.03$ & $6.52 \mathrm{a} \pm 0.05$ & $6.52 \mathrm{a} \pm 0.02$ \\
\hline $\mathrm{R}(\mathrm{s})^{\mathrm{b}}$ & $933 a \pm 71$ & $821 \mathrm{a} \pm 80$ & $1106 \mathrm{~b} \pm 53$ & $891 \mathrm{a} \pm 71$ & $957 \mathrm{ab} \pm 104$ & $1069 \mathrm{~b} \pm 53$ \\
\hline $\mathrm{K} 20(\mathrm{~s})^{\mathrm{c}}$ & $171 \mathrm{a} \pm 17$ & $139 a \pm 19$ & $217 \mathrm{~b} \pm 12$ & $159 \mathrm{a} \pm 17$ & $143 a \pm 25$ & $210 b \pm 13$ \\
\hline $\mathrm{A} 30(\mathrm{~mm})^{\mathrm{d}}$ & $52.4 \mathrm{a} \pm 3.9$ & $59.9 \mathrm{a} \pm 4.4$ & $41.7 \mathrm{~b} \pm 3.0$ & $51.7 \pm 3.9$ & $55.1 \pm 5.3$ & $44.9 \pm 3$ \\
\hline
\end{tabular}

a,b, ..: within the row and for the same DIM, means with different letters differ $(P<0.05)$.

${ }^{a}$ Type $1=$ short lactation initiated in autumn; Type $2=$ short lactation initiated in spring; Type $3=$ long lactation initiated in autumn.

${ }^{\mathrm{b}}$ Renneting time.

${ }^{\mathrm{c}}$ Rate of firming.

${ }^{\mathrm{d}}$ Curd firmness.

Fig. 2 shows fat and lactose content and Fig. 3 protein and casein content for each type of lactation. Fat, protein and casein content tended to increase with DIM, as reported by Casoli et al. (1989), Ubertalle et al. (1991), Fadel et al. (1989), Duranti et al. (1990), Marìa and Gabiña (1993), Carta et al. (1995), Hassan (1995) and Cappio-Borlino et al. (1997). The three lactation types were found to differ in lipid synthesis levels. Type 2 (spring/short) showed the greatest increase in fat content, leading at 93.7 DIM to a level about 1.5 percentage points above the other two (Table 3). In particular, comparison of Type 2 with Type 1 lactation, which occurred in the same ewes, and in which about the same amount of milk was

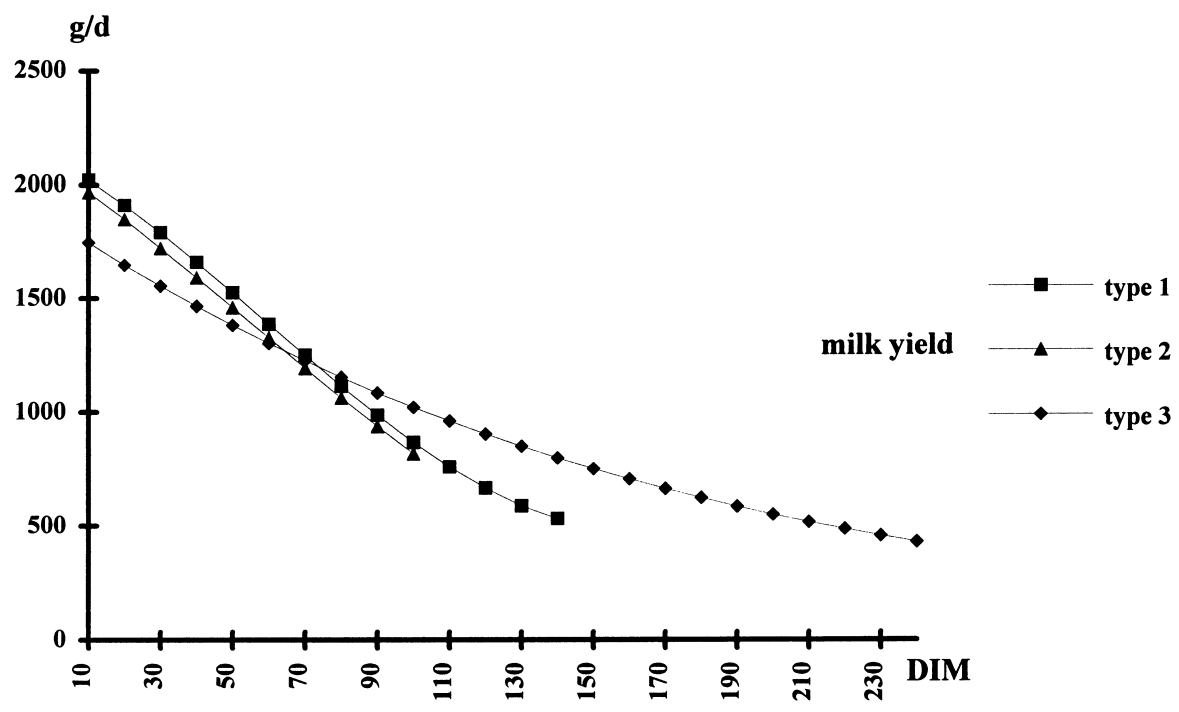

Fig. 1. Evolution on DIM of daily milk yield for Type 1 (short, initiated in autumn), Type 2 (short, initiated in spring), and Type 3 (long, initiated in autumn) lactations. 


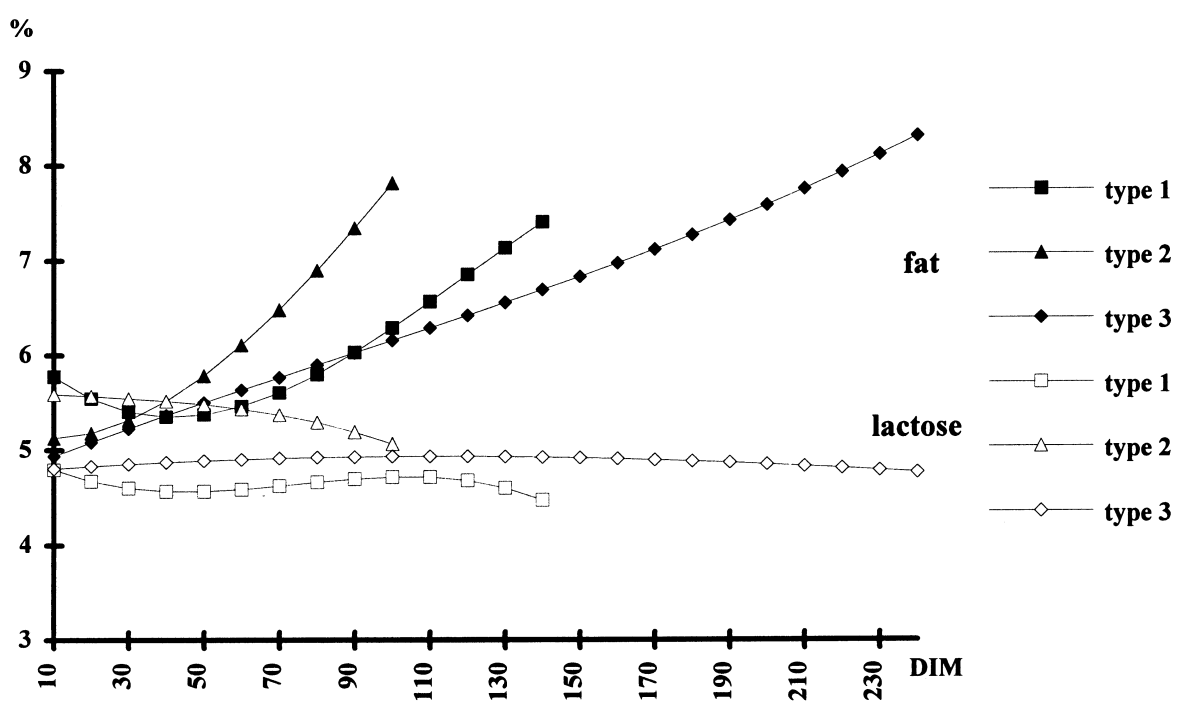

Fig. 2. Evolution on DIM of fat and lactose content for Type 1 (short, initiated in autumn), Type 2 (short, initiated in spring), and Type 3 (long, initiated in autumn) lactations.

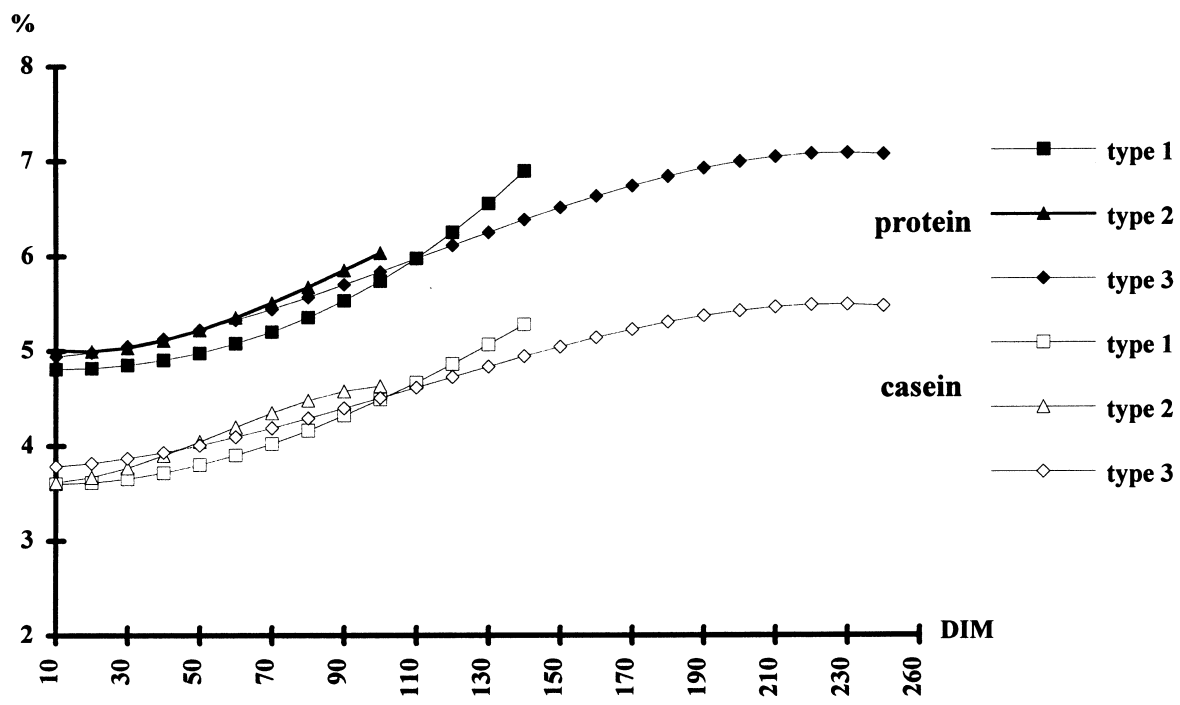

Fig. 3. Evolution on DIM of protein and casein content for Type 1 (short, initiated in autumn), Type 2 (short, initiated in spring), and Type 3 (long, initiated in autumn) lactations.

produced, suggests that the higher fat content of Type 2 lactation was due to better feeding conditions in spring with more abundant pasturage when the sheep were still at the early lactation stage.

Differences between the lactation types were smaller for protein content, probably because this parameter exhibits smaller variation than fat content, being less affected by environmental factors. The estimates of Table 3 nevertheless show that in Type 1 lactation (autumn/short) protein content tended to be somewhat lower than in the other two types. Differences between Type 1 and Type 3 lactation 


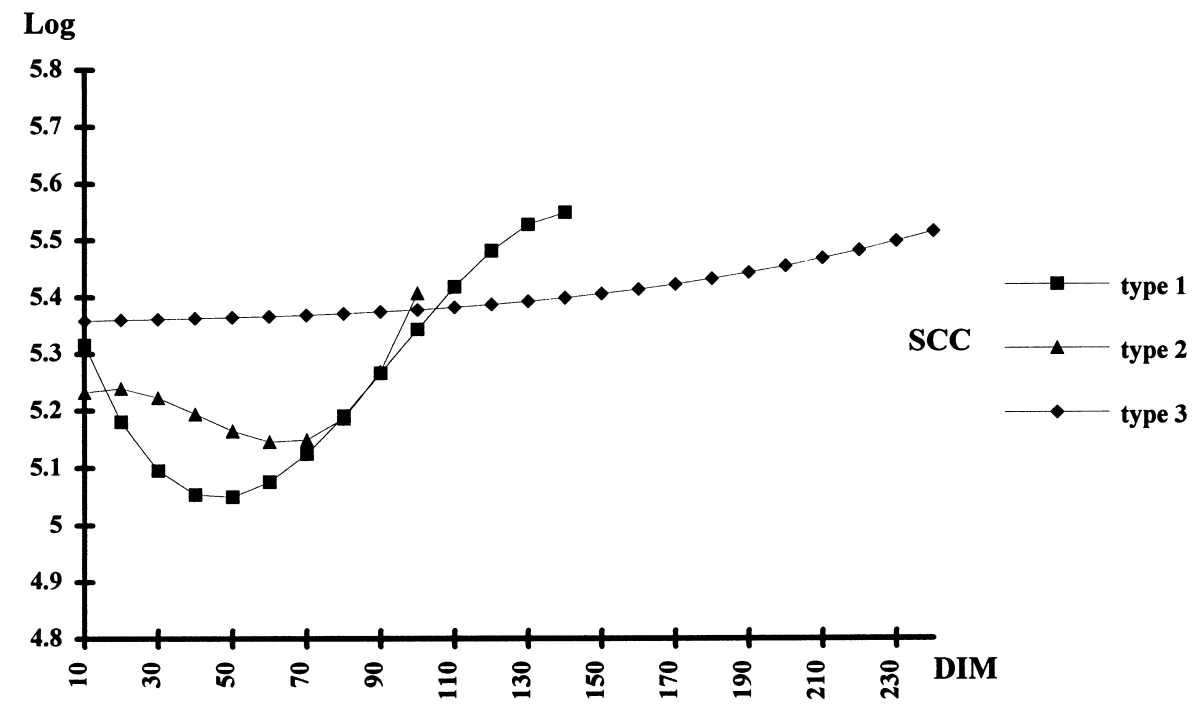

Fig. 4. Evolution on DIM of somatic cell count $(\log (\mathrm{SCC}))$ for Type 1 (short, initiated in autumn), Type 2 (short, initiated in spring), and Type 3 (long, initiated in autumn) lactations.

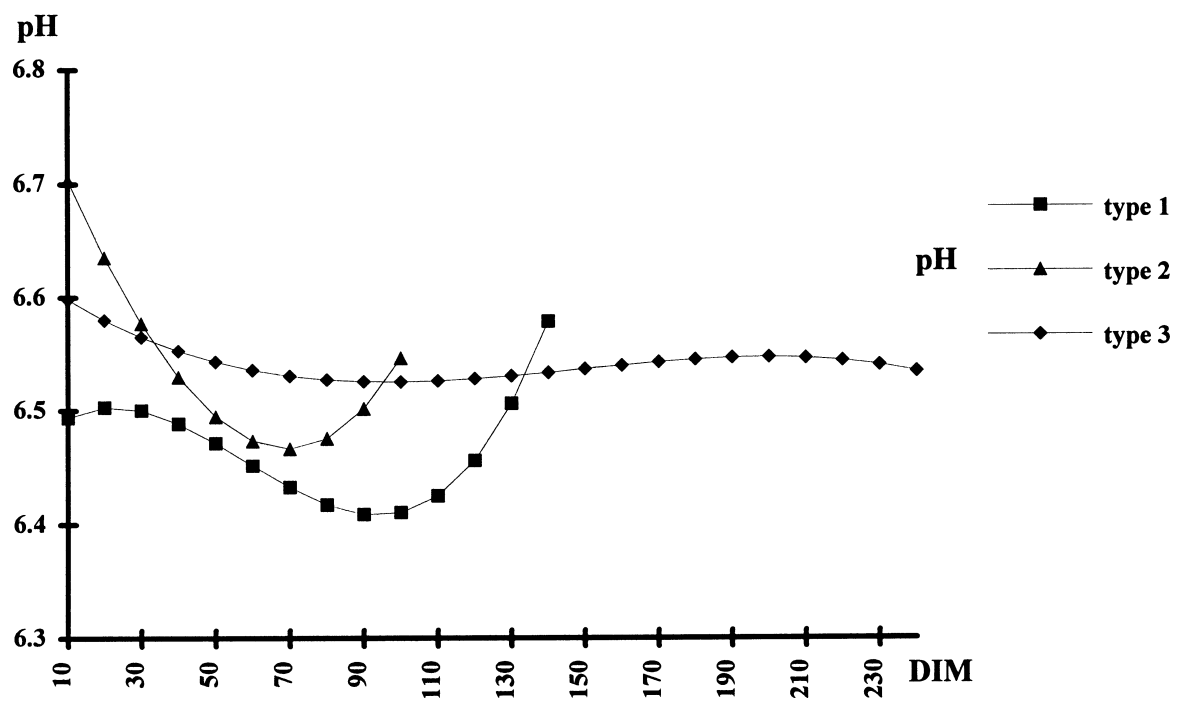

Fig. 5. Evolution on DIM of pH for Type 1 (short, initiated in autumn), Type 2 (short, initiated in spring), and Type 3 (long, initiated in autumn) lactations.

(which, however, became evident only at 45 DIM) seemed related to the amount of milk produced and also to the slight delay of about one month in the start of lactation of Type 3 .

Lactose content tended to remain constant over the entire lactation with perhaps a slight decrease with
DIM for the short lactations. Evolution of lactose therefore differed from both fat and protein, agreeing with other researchers (Casoli et al., 1989; Pellegrini et al., 1994). As regards SCC, Type 1 and Type 2 lactation differed from Type 3 (Fig. 4) though when compared point by point (Table 3 ) the differences 


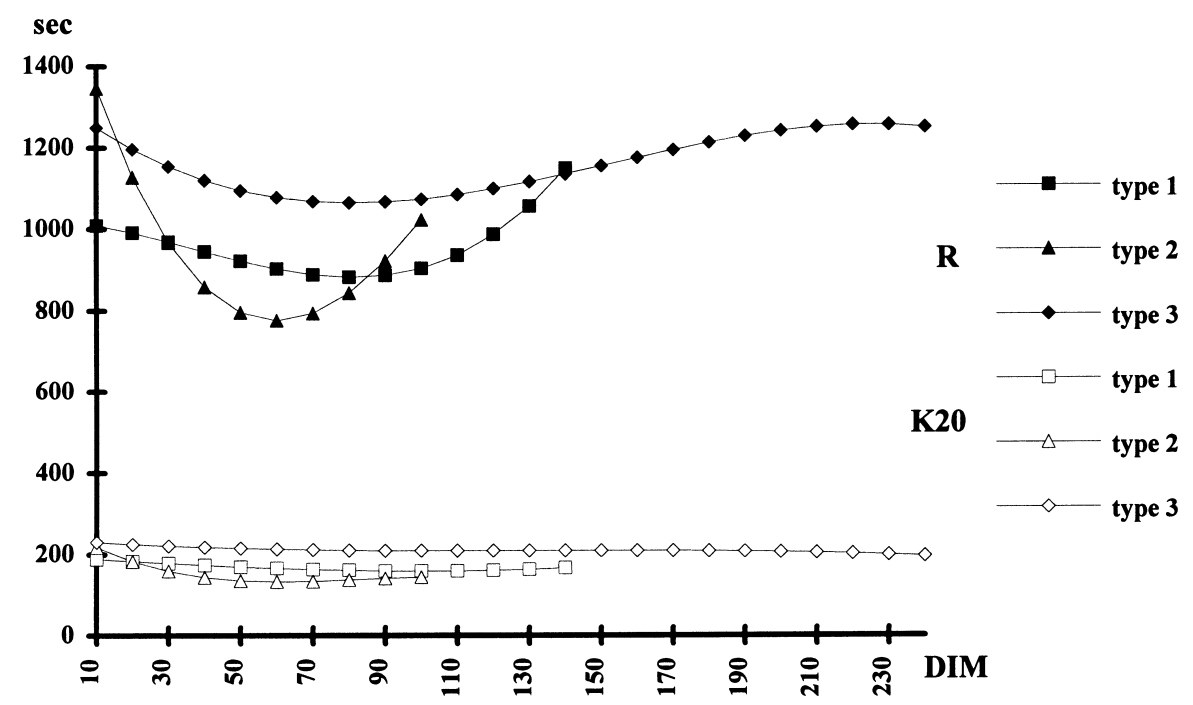

Fig. 6. Evolution on DIM of renneting time (R) and rate of firming (K20) for Type 1 (short, initiated in autumn), Type 2 (short, initiated in spring), and Type 3 (long, initiated in autumn) lactations.

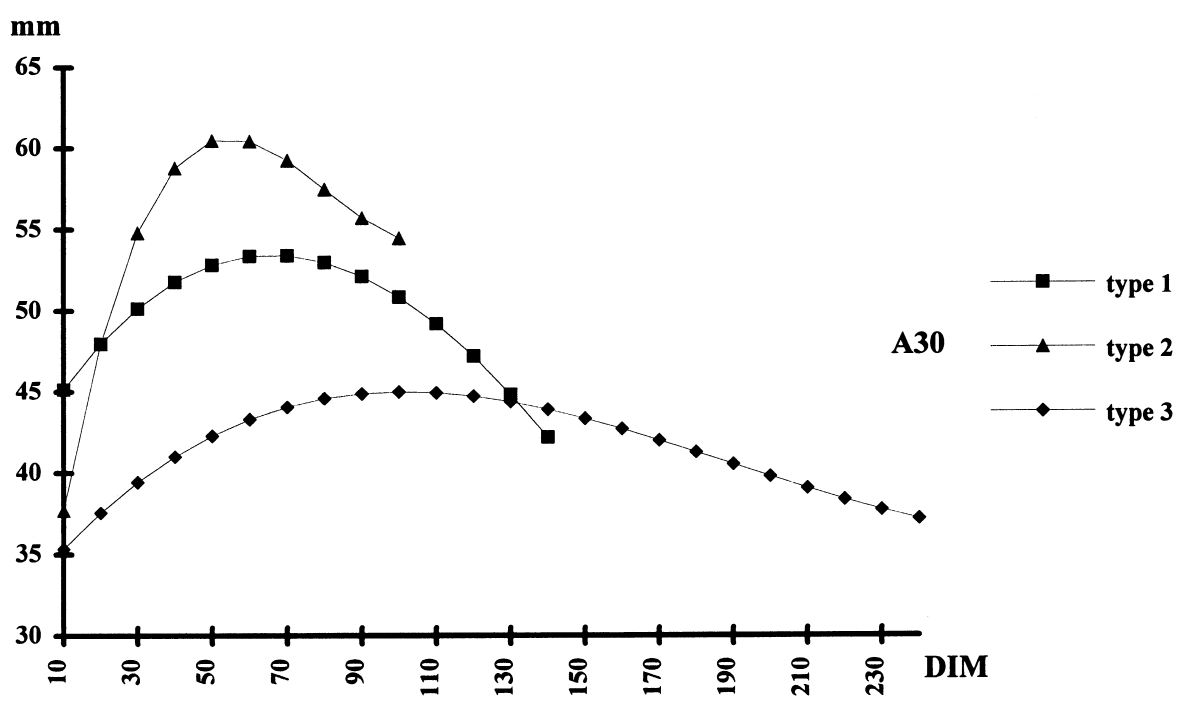

Fig. 7. Evolution on DIM of curd firmness (A30) for Type 1 (short, initiated in autumn), Type 2 (short, initiated in spring), and Type 3 (long, initiated in autumn) lactations.

were not statistically significant. It is possible however that the greater similarity between Type 1 and Type 2 in the SCC was due to the fact that the same animals were used. As lactation progressed there was generally an increase in the SCC, probably because of a 'concentration effect', but this effect cannot be the whole explanation for the pattern observed since in the short lactations the minimum SCC fell between day 40 and day 70 , which was fairly distant from peak yield. Lagriffoul et al. (1996) on the Lacaune breed also reported the lowest SCC between day 45 and day 85 postpartum. 
The evolution of $\mathrm{pH}$ and lactodynamographic parameters are shown in Figs. 5-7. The findings appear consistent with each other and generally indicate that within each type of lactation there was a substantial improvement in cheese-making suitability during the first 2-3 months postpartum, and a worsening thereafter, which however tended to diminish with time, as shown in the long Type 3 lactation. The evolution of the lactoynamographic parameters was consistent with Ubertalle et al. (1991) on Delle Langhe sheep, and with Delacroix-Buchet et al. (1994) on Lacaune. The curves for R, K20 and A30 ran mainly parallel for the Type 1 and Type 3 lactations, while for Type 2 patterns they were more variable, probably because of the change of feeding regimen in spring combined with the early lactation stage. On the whole Type 2 lactation gave better results, though on specific points, comparison with Type 1 was not significant (Table 3), probably because Type 1 lactation occurred in the same subjects as Type 2 .

\section{Conclusions}

The present study examined some of the major factors that affect milk quality in Massese sheep under extensive management system normal for this breed. The exclusion of first-parity sheep from the study greatly reduced variation due to lactation order, although the greater nutrient content of milk from mature ewes was confirmed. As regards SCC and the technological characteristics the best milk came from second-parity ewes, at least when compared with fourth-parity animals. The absence of a reduction in milk quality after the fourth lactation suggests farmer selection operating on the basis of udder health.

The comparison among the three types of lactation, which Massese ewe can produce, must be regarded with caution in a one-year study, since inevitably there is partial confusion between the two factors of type of lactation and animal, inasmuch as some subjects are the same for two of the three types of lactation. In that context the expected increase in the concentration of milk nutrients with increasing DIM was particularly noticeable for fat content in the spring/short lactation, showing that the favourable effect, in both quantity and quality, of the resumption of growth on pastureland in spring was expressed most clearly in ewes that had newly started lactation. The same spring/short lactation also yielded milk with better renneting properties, at least after the first month, which is when it begins to be used for cheese making. Particularly, milk from this type of lactation was better than milk obtained during the same season from ewes that had an autumn delivery. This suggested that the newly started milk from the spring lactation could have a 'corrective' effect on the total amount of bulk milk produced and intended for cheese-making. This benefit would ensure a good degree of bulk milk homogeneity during the year and also suggests that a deseasonalisation of lambings is a worth-while character in the Massese breed.

\section{Acknowledgements}

The authors acknowledge financial support from Ministero Università e Ricerca Scientifica e Tecnologica (40\% and $60 \%$ fund).

\section{References}

ASPA, 1995. Metodi di analisi del latte delle principali specie di interesse zootecnico (Methods of milk analysis for the principal dairy animals). Università degli Studi di Perugia Ed., pp. 1224.

Barillet, F., 1985. Amélioration génétique de la composition de lait des brebis. L'example de la race Lacaune (Genetic improvement for ewe milk composition. The case of Lacaune breed). Ph.D. Thesis, INRA Paris-Drignon, 144 pp.

Barillet, F., Boichard, D., 1987. Studies on dairy production of milking ewes I. Estimates of genetic parameters for total milk composition and yield. Génét. Sél. Evol. 19, 459-474.

Bergonier, D., Lagriffoul, G., Berthelot, X., Barillet, F., 1996. Facteurs de variation infectieux des comptages de cellules somatiques chez les ovins et caprins latiers (Non-infectious factors of somatic cell count variation in dairy ewes and goats). In: Rubino, R. (Ed.), Proc. of the Inter. Symposium on Somatic Cells and Milk of Small Ruminants, Bella, Italy, EAAP Publication no. 77, 25-27 September 1994, pp. 113-135.

Bertoni, G., 1996. Ambiente, alimentazione e qualità del latte (Environment, feeding and milk quality). Informatore Agrario 52(Suppl.), 5-41.

Cappio-Borlino, A., Portolano, B., Todaro, M., Macciotta, N.P.P., Giaccone, P., Pulina, G., 1997. Lactation curves of Valle del Belice dairy ewes for yields of milk, fat, and protein estimated with test day models. J. Dairy Sci. 80, 3023-3029.

Carta, A., Sanna, S.R., Casu, S., 1995. Estimation lactation curves and seasonal effects for milk, fat and protein in Sarda dairy sheep with a test-day model. Livest. Prod. Sci. 44, 37-44. 
Casoli, C., Duranti, E., Morbidini, L., Panella, F., Vizioli, V., 1989. Quantitative and compositional variations of Massese sheep milk by parity and stage of lactation. Small Rumin. Res. 2, 4762.

Delacroix-Buchet, A., Barillet, F., Lagriffoul, G., 1994. Caractérisation de l'aptitude fromagère des laits de brebis Lacaune à l'aide d'un Formagraph (Characterization of cheese making properties of individual Lacaune ewe milk samples with a Formagraph). Lait 74, 173-186.

Duranti, E., Casoli, C., Vizioli, V., 1990. Composizione e qualità tecnologiche del latte di pecora di razza Massese (Composition and technological properties of milk of Massese ewe). Proc. IX Congr. Naz. SIPAOC, Grado 20-22 giugno.

Fadel, I., Owen, J.B., Kassem, R., Juha, H., 1989. A note on the milk composition of Awassi ewes. Anim. Prod. 48, 606-610.

Flamant, J.C., Casu, S., 1977. Amélioration génétique de la production laitière des brebis Sardes. II. Facteurs de variation génétiques et non génétiques des performances de brebis ayant réalisé 2 lactations (Genetic improvement of milk yield in Sardinian ewes. II. Genetic and non-genetic factors of variation of performances of ewes having done 2 lactations). Ann. Génét. Sél. Anim. 9, 203-217.

Franci, O., Pugliese, C., Acciaioli, A., Parisi, G., Lucifero, M., 1999. Application of two models to the lactation curve of Massese ewes. Small Rumin. Res. 31, 91-96.

Gonzalo, C., Carriedo, J.A., Baro, J.A., San Primitivo, F., 1994. Factors influencing variation of test day milk yield, somatic cell count, fat, and protein in dairy sheep. J. Dairy Sci. 77, 15371542.

Hassan, H.A., 1995. Effects of crossing and environmental factors on production and some constituents of milk in Ossimi and Saidi sheep and their crosses with Chios. Small Rumin. Res. 18, $165-172$
Lagriffoul, G., Bergonier, D., Berthelot, X., Jacquin, M., Guillouet, P., Barillet, F., 1996. Facteurs de variation génétiques et non génétiques des comptages de cellules somatiques du lait de brebis en relation avec les caractères laitiers et les mesures portant sur le lait du tank (Genetic and non-genetic factors of variation of somatic cell counts in ewes' milk in relation to milk characters and to measurements in the bulk milk). In: Rubino, R. (Ed.), Proc. of the Inter. Symp. on Somatic Cells and Milk of Small Ruminants, Bella, Italy, EAAP Publication no. 77, 25-27 September 1994, pp. 149-155.

Marìa, G., Gabiña, D., 1993. Non-genetic effects on milk production of Latxa ewes. Small Rumin. Res. 12, 61-67.

Peeters, R., Buys, N., Robijns, L., Vanmontfort, D., Van Isterdael, J., 1992. Milk yield and milk composition of Flemish Milksheep, Suffolk and Texel ewes and their crossbreds. Small Rumin. Res. 7, 279-288.

Pellegrini, O., Remeuf, F., Rivemale, M., 1994. Évolution des caractéristiques physico-chimiques et des paramètres de coagulation du lait de brebis collecté dans la région de Roquefort (Evolution of physico-chemical characteristics and renneting properties of ewe's milk collected in the 'Roquefort area'). Lait 74, 425-442.

Sakul, H., Boylan, W.J., 1992. Evaluation of US sheep breeds for milk production and milk composition. Small Rumin. Res. 7, 195-201.

SAS, 1996. SAS/STAT User's guide. 6.11 version. SAS Institute Inc., Cary, NC, USA.

Ubertalle, A., Errante, J., Fortina, R., Ambrosoli, R., 1991. Comportamento reologico e variazioni di alcuni parametri fisico-chimici e biologici del late ovino (Renneting ability and variations of some chemical, physical and biological parameters of sheep milk). Proc. of the IX Congress on ASPA, ISMEA, Roma, pp. 999-1008. 